\section{SPOLIA ATLANTICA}

Spolia Atlantica. (I) Contributions to the Knowledge of the Salpidæ, by M. P. A. Traustedt ; (2) Remarks on some of the Oceanic Annulata, by G. M. R. Levinsen ; (3) Contributions towards the Morphology and Systematic Arrangement of the Pteropoda, by J. E. V. Boas. (Copenhagen, 1885-86.)

THE three monographs which at the instance, and under the supervision, of the Directors of the Zoological Museum of Copenhagen, have been included in one quarto volume under the title of "Spolia Atlantica," originally appeared in the Transactions of the Danish Royal Society of Natural Sciences. But although bound together, each monograph in this édition de luxe is complete in itself, with separate title-page, table of contents, descriptive plates, and all other necessary means of separate reference, while the convenience of readers not acquainted with Danish has been amply considered by the addition of Latin and French translations of the descriptions of the animals, and of many other important parts of the text.

The first of this triplet of monographs, which deals with the so-called "aggregate" and "solitary" forms of the several species of Salpæ, is based on a study of the exceptionally complete collections preserved in the Zoological Museum of Copenhagen, for which that institution is mainly indebted to Prof. Steenstrup, at whose suggestion and under whose direction Herr Traustedt compiled his memoir. The monograph presents a clear and comprehensive description of all the well-established species of Salpæ with their distinctive dual forms, and unqualified praise may be given to the care with which the figures have been drawn, and the admirable manner in which, by means of pale blue outlines, the delicacy and transparency of the bodies of the animals have been represented.

In treating of the Salpidæ, it is impossible to forget how much of our knowledge of these curious animals is due to the observations of Chamisso, the clever author of "Peter Schlemihl," who, while serving as naturalist in the exploring expedition of the Russian commander Kotzebue, first discovered that the "aggregate" or chain Salpa and the "solitary" Salpa were not distinct species, as had been supposed, but only parts of the perfect organism of one species. By the discovery of this fact, which Chamisso ingeniously, but, as subsequent investigations have shown, too fancifully, explained on the hypothesis that these animals were subject to a law of "alternation of generations," new and highly important paths of morphological inquiry were opened. Yet, singularly enough, nearly thirty years passed after the publication, in 1819, of Chamisso's treatise “ De Animalibus quibusdam e Classe Vermium Linneana (de Salpis)" before his observations were tested by further scientific investigation. About the middle of the century Meyen and Vogt turned their attention to the curious and interesting phenomena connected with the embryonic development of the Salpæ. These inquiries were soon followed by the still more important researches of Profs. Krohn and Huxley, the latter of whom in a paper entitled "Observations upon the Anatomy and Physiology of Salpa and Pyrosoma," which appeared in the Phil. Trans. I $85 \mathrm{r}$, has shown that Chamisso erred in his explanation of the nature of a "chain Salpa," which, to use Mr. Huxley's words, "is nothing more homologically than a highly individualised generative organ."

Herr Traustedt does not enter into the question of the embryonic development of the Salpidæ, and hence his work gives no information regarding the physiology of these animals, nor does he in any way refer to the various hypotheses that have been advanced in explanation of the character of the "aggregate" and "solitary" forms. For such information the student must go elsewhere. As a guide to the anatomical structure of both forms in the eleven species described and drawn by the author, the memoir will, however, be found of great service, while it contains much useful information as to the geographical distribution of these animals not to be found elsewhere.

In the treatise on "Some Oceanic Annulata" Herr Levinsen supplies many interesting details regarding various members of the families Alciopidæ and Typhloscolecidæ, together with descriptions of several species of Sagitta, to which are added lists of their geographical distribution. In this, as in the memoir on the Pteropoda, the illustrations are worthy of all praise.

The memoir by Dr. Boas, which constitutes the last and longest of the series, treats at great length of the morphology, systematic arrangement, and geographical distribution of the Pteropoda. The materials employed by the author were derived in part from the extensive collections in the Zoological Museum of Copenhagen made by, or under the direction of, Prof. Steenstrup, and in part from numerous specimens placed at the writer's disposition by Profs. Dohrn, Möbius, Leche, and Spengel. It is worthy of note that a very large proportion of the specimens referred to as belonging to the Museum of Copenhagen were obtained from amateur collectors; Danish naval officers, captains of merchant ships, and travellers having responded with alacrity to Prof. Steenstrup's appeal for help in obtaining samples of these and other animals from remote regions.

\section{OUR BOOK SHELF}

Complete Hand-book on the Management of Accumulators. By Sir David Salomons, Bart. Second Edition, revised and enlarged. (London: Whittaker and Co., I 887.)

THE author has for some years past had an installation at his country residence for the purpose of lighting it and for working motors which drive the machinery in his large and well-equipped workshop. He has used accumulators, as he informs us, ever since they may be said to have been produced in commercial form in 1882 . No expense nor trouble have been spared in making this installation a model one, and experiments have been made on many points in connexion with the subject. As the whole installation has been made and worked under his immediate personal superintendence, he has acquired a considerable amount of experience, the result of which, as far as it regards the management of accumulators, he places before the public in this work.

After a general description of cells of the E.P.S. and Elwell-Parker type, he proceeds to give directions for setting up and charging them. The causes of, and remedies for, "buckling" and "scaling" are discussed. The harm caused by too rapid a discharge is pointed out, and methods for preventing it are explained, as well as various devices for regulating the E.M.F. of the charging current and that on the line. The method of cleaning and "re-pasting" the plates is explained, and various 